Karakteristik Desain ... (Cadelina C., Ratna S., dan Riswan E.)

\title{
KARAKTERISTIK DESAIN SOCIAL COMMERCE TERHADAP KEPUASAN PELANGGAN
}

\author{
Cadelina Cassandra ${ }^{1}$, \\ Ratna Sari², \\ Riswan Efendi Tarigan ${ }^{3}$
}

Pascasarjana Magister Sistem Informasi, Fakultas Ilmu Komputer, Universitas Bina Nusantara Kampus Anggrek, Jl. Kebon Jeruk Raya No. 27, Jakarta, 11530

e-mail: ccassandra@binus.edu ${ }^{1)}$, rasari@binus.edu ${ }^{2}$, retarigan@ binus.ac.id ${ }^{3)}$

\begin{abstract}
Abstrak
Social commerce sedang menjadi tren bagi perusahaan online saat ini. Perkembangan Social Networking Site dan web 2.0 mendukung evolusi dari e-commerce dan membuka peluang baru bagi perusahaan untuk masuk ke dalam pasar baru. Perubahan pola perilaku pengguna internet dari yang kaku menjadi aktif dan komunikatif membuat social commerce diyakini dapat memberikan keuntungan bagi perusahaan online namun ternyata tidak semua perusahaan berhasil menerapkan social commerce dan menarik pelanggan, tidak sebanding dengan biaya yang telah dikeluarkan. Penelitian ini bertujuan untuk mempelajari apa yang mendasari kepuasan pelanggan dalam melakukan proses pembelanjaan secara online melalui social commerce dan menguji apakah benar karakteristik sebuah social commerce memang cocok untuk mendukung kepuasan pengguna dalam berbelanja sehingga didapatkan rekomendasi yang tepat bagi pebisnis baru yang ingin mengadopsi social commerce ke depannya mengingat tren media sosial semakin berkembang di masyarakat. Metode penelitian dalam penelitian ini adalah metode kuantitatif dan studi literatur terkait dengan isu yang dibahas. Hasil yang didapatkan adalah ternyata faktor kualitas informasi yang paling berpengaruh terhadap kepuasan pelanggan jika dibandingkan faktor karakteristik social commerce lainnya.
\end{abstract}

Keywords: social commerce, social networking site, web 2.0, media sosial. 


\section{PENDAHULUAN}

Perkembangan media sosial dan SNS (Social Networking Site) serta dukungan dari web 2.0 telah mengubah lingkungan online menjadi lebih interaktif. Hal ini memicu interaksi sosial diantara seluruh pengguna internet yang dapat diakses dengan mudah tak terkecuali untuk pelanggan yang biasa berbelanja online. (Huang \& Benyoucef, 2013). Perubahan ini juga turut mengubah pola pikir dan perilaku pelanggan menjadi memiliki kebebasan untuk saling berbagi pengetahuan dan pengalaman yang mereka dapatkan ketika berbelanja secara online melalui berbagai media sosial dan dapat berkomunikasi secara langsung untuk memberikan komentar mengenai produk dan jasa, rating, rekomendasi, dan sebagainya. Hal inilah yang menyebabkan, perusahaan- perusahaan baru atau pun yang sudah ada mulai bergerak ke arah social commerce.

Praktik dari social commerce juga sudah banyak digunakan oleh pembeli dan penjual online di Indonesia, contoh yang paling sederhana adalah memanfaatkan media social seperti facebook dan twitter untuk menawarkan produk dan pelanggan dapat menulis seluruh review di halaman facebook atau twitter tersebut. Hal ini juga didukung oleh pertumbuhan pengguna internet di Indonesia yang saat ini telah mencapai angka $34,9 \%$ sehingga membuka peluang baru bagi pasar online di Indonesia. (Pangerapan, 2015)

Tak berbeda dengan e-commerce, social commerce juga melibatkan pelanggan sebagai faktor utama penentu kesuksesan suatu bisnis. Tujuan bisnis dari perusahaan seharusnya dapat memenuhi keinginan pelanggan, dan berusaha untuk selalu menjaga pelanggan agar tidak beralih (Alshibly, 2014). Ini menjadi tugas dari seluruh perusahaan untuk mempertahankan kepuasan dan kepercayaan pelanggan agar tetap setia terhadap perusahaan tersebut.

Cheung dan Lee (2005) menunjukkan bahwa $80 \%$ pelanggan online yang puas akan belanja kembali sekitar dalam waktu 
dua bulan, dan $90 \%$ akan commerce diperkirakan akan berkembang merekomendasikan kepada orang lain. Di dan memberikan keuntungan sebanyak sisi lainnya, 87\% pelanggan online yang US\$30 milyar pada tahun 2015. (Zhou, tidak puas tidak akan mengunjungi kembali Zhang, \& Zimmwemann, 2013). secara permanen, sehingga hanya Diperkirakan bahwa pertumbuhan dari perusahaan yang dapat mengelola social commerce akan meningkat $43 \%$ hubungan yang baik dengan pelanggan dan setiap tahunnya dan $88 \%$ bisnis berencana memberikan kepuasan kepada pelanggan yang akan bertahan. Perusahaan yang ingin mengadopsi social commerce dalam pengembangan bisnisnya memiliki resiko yang cukup besar karena kekuatan pelanggan menjadi lebih besar dari biasanya, perusahaan harus menjaga kepuasan pelanggan sebaik-baiknya agar komentar dan berita yang tersebar merupakan informasi yang mendukung perusahaan. Salah satu dampak dari kepuasan pelanggan dalam jangka panjang adalah dapat meningkatkan keuntungan atau pendapatan perusahaan, sehingga inilah hal yang dapat membuat perusahaan bertahan (Luo, 2013).

Social commerce telah mendapatkan perhatian yang cukup banyak oleh perusahaan online di berbagai negara. Di untuk mengadopsi social commerce di masa mendatang. (Constantinides, 2008)

Namun berbanding terbalik dengan keinginan perusahaan untuk mengadopsi social commerce ke depannya, ternyata keunggulan interaktif social commerce tidak sepenuhnya disukai oleh pelanggan, pelanggan lebih cenderung mempercayai dan menyukai e-commerce dibandingkan social commerce (Bansal \& Chen, 2011). Hal ini mengartikan bahwa tidak semua perusahaan berhasil mengadopsi social commerce, ada hal-hal yang perlu diketahui untuk dapat memuaskan pelanggan. Banyak hal yang mendukung kepuasan pelanggan dalam interaksinya melalui pembelian online. Huang dan Beyoucef (2013) mendeskripsikan prinsip desain dari social commerce yang harus ada pada sebuah Amerika serikat, pasar dari social website social commerce, dengan 
mengikuti prinsip tersebut sebuah social commerce dapat memenuhi keinginan pelanggannya.

Oleh karena itu, pada penelitian ini penulis tertarik untuk menginvestigasi faktor-faktor apa saja yang mendukung kepuasan pelanggan social commerce jika dilihat dari karakteristik social commerce dan membuktikan bahwa karakteristik social commerce memang telah sesuai dengan keinginan pelanggan saat ini.

\section{TINJAUAN TEORI DAN PENGEMBANGAN HIPOTESIS} Istilah social commerce diperkenalkan pertama kali oleh yahoo untuk digunakan pada kolaborasi online yahoo dan rating oleh pengguna pada tahun 2005, istilah social commerce kemudian dikenal hingga saat ini. (Saundage \& Lee, 2011).

Social commerce merupakan area bisnis baru dari e-commerce yang menggabungkan SNS (Social Networking Site) dimana keunggulan dari e-commerce ataupun interaksi sosial dari SNS dapat dirasakan keduanya di social commerce
(Jung, 2014). Meskipun social commerce sering dikaitkan dengan e-commerce, terdapat perbedaan diantara keduanya (Huang \& Beyoucef, 2013). Adapun perbedaannya terletak pada:

a. Tujuan bisnisnya (business goals)

Dimana jika dilihat dari tujuan bisnis, $e$ commerce fokus dalam memaksimalkan efisiensi melalui strategi pencarian barangnya, pembelian dalam sekali klik (one click buying), penyediaan katalog, dan fokus pada transaksi semudah mungkin dan sebanyak mungkin sedangkan social commerce berorientasi kepada tujuan sosial terlebih dahulu seperti networking, kolaborasi, berbagi informasi, dan fokus yang kedua baru berbelanja setelah interaksi sosialnya tercapai.

b. Hubungan antar pelanggan (customer connection)

Pada e-commerce pelanggan biasanya berinteraksi secara individu dan independen dari pelanggan yang lainnya, tidak ada komunikasi langsung dan hanya memiliki tujuan membeli barang saja sedangkan social commerce 
Karakteristik Desain ... (Cadelina C., Ratna S., dan Riswan E.)

pasti melibatkan komunitas online yang mendukung percakapan dan komunikasi antar pelanggan

c. Interaksi sistem (system interaction)

Interaksi sistem pada e-commerce hanyalah sebatas browsing dan membeli, dimana informasi dari pelanggan setelah membeli hanya satu arah atau bahkan tidak ada feedback untuk perusahaan, sedangkan social commerce lebih mengembangkan aspek sosial dan interaktif yang menjadikannya wadah bagi pelanggan untuk berbagi pengalaman, rekomendasi, rating, komentar kepada sesama pelanggan atau bahkan penjual.

\section{Penelitian Terdahulu}

Penelitian yang telah ada sebelumnya tentang social commerce lebih banyak menarik peneliti untuk melihat kepada konsep dan model social commerce dan karakteristiknya. Dengan ciri social commerce yang berbeda, muncul pula karakteristik social commerce yang berbeda-beda. Huang dan Beyoucef (2013) mendefinisikan prinsip desain dari social commerce yang menekankan aspek sosial. Model karakteristik desain social commerce oleh Huang dan Beyoucef (2013) menghasilkan model karakteristik fitur desain social commerce yang terdiri dari 4 lapisan utama yaitu: Individual, digambarkan sebagai lapisan yang pertama dalam model yang dibuat, lapisan ini merepresentasikan yang disebut dengan "the self". Hal ini menunjukkan bahwa social commerce menampilkan sisi individu yang ingin menunjukkan dirinya, ingin dianggap ada, dan ingin bersosialisasi; Conversation, merupakan lapisan kedua pada model social commerce. Mengapa aspek ini perlu diperhatikan dalam desain social commerce adalah dikarenakan individu dapat mengekspresikan diri mereka sendiri melalui postingan dan berbagi kepada individu lainnya. Tanpa adanya conversation, tidak ada informasi yang diperoleh. Conversation menekankan kepada interaksi antar individu dan komunikasi dua arah, dan fokus kepada pendekatan yang memungkinkan 
pelanggan untuk mendengar dan berbicara; Community, merupakan lapisan ketiga. Dengan adanya individu dan conversation sehingga menciptakan sebuah komunitas dari interkasi tersebut. Komunitas sangat penting bagi sebuah social commerce, dengan memiliki komunitas dengan preferensi tertentu, penjualan produk akan menjadi lebih mudah; dan Commerce, merupakan aspek yang diambil dari e-commerce dikarenakan social commerce masih berkaitan dengan e-commerce dan penjualan seperti transaksi pembelian dan mekanisme pembayaran.

Dari sisi kualitas website, Alsibly (2014) mengidentifikasi beberapa karakteristik yang dapat diuji dalam website social commerce, diantaranya: Kualitas Informasi, termasuk didalamnya yang dimaksud dengan kualitas informasi adalah relevansi, penghematan waktu, dan akurasi dari informasi yang disampaikan; Kualitas Sistem, diukur dari perspektif teknis pada website. Sebelum menghasilkan sebuah informasi yang menarik, website haruslah mudah diakses dan memiliki desain yang menarik.

Lebih jauh lagi, penelitian mulai mengarah kepada bagaimana social commerce akhirnya dapat mempengaruhi pelanggan karena semakin banyak perusahaan online yang mengadopsi social commerce tersebut. Dengan adanya ketertarikan dan persiapan website online yang baik, kepuasan pelanggan akan terbentuk dan akhirnya keputusan pembelian akan dilakukan oleh pelanggan. Kepuasan pelanggan tersebut dapat membawa keuntungan jangka panjang bagi organisasi. (Eid, 2011)

Kepuasan pelanggan menentukan bagaimana perusahaan tersebut dapat bertahan dan sukses. (Anderson \& Mittal, 2000). Website jual beli online dapat dikatakan sukses jika berhasil membuat pelanggan puas dan mengunjunginya kembali. Pelanggan yang puas dengan website tersebut dipastikan akan bersedia untuk berlama - lama mengunjungi website tersebut dan bersedia untuk mengunjunginya kembali 
Karakteristik Desain ... (Cadelina C., Ratna S., dan Riswan E.)

bahkan merekomendasikan kepada interaksi sosial dan hubungan pelanggan orang lain. (Zhang \& Dran, 2001). Hingga adalah pembeda antara social commerce saat ini, beberapa penelitian tentang dan e-commerce pada umumnya.

memprediksi kepuasan pelanggan Model Penelitian

terhadap social commerce telah Pengujian model karakteristik social dilakukan seperti Alsibly (2014) yang commerce diuji dengan menggunakan melakukan penelitian dengan empat variabel Independent (X) yaitu mengambil faktor kualitas sistem dan variabel fasilitias individu, fasilitas kualitas informasi pada website social komunikasi, kualitas informasi, dan kualitas commerce dalam mempengaruhi sistem dan satu variabel dependent (Y) kepuasan pelanggan, namun belum yaitu Kepuasan Pelanggan. Lebih rinci banyak penelitian yang menguji penjelasan tentang masing-masing variabel karakteristik utama social commerce tersebut akan dijelaskan kemudian didalam berupa interaksi sosial dan hubungan antar pelanggan secara spesifik untuk menguji kepuasan pelanggan padahal yang dilakukan oleh penulis: hipotesis yang terbentuk.

Berikut adalah gambaran model penelitian

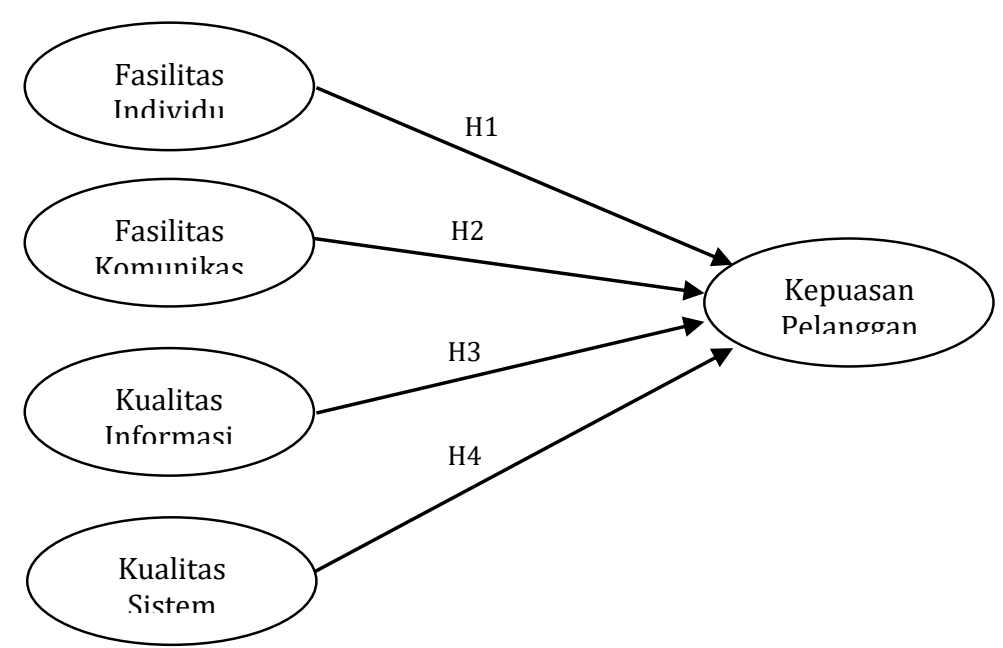

Gambar 1. Model Penelitian 
Dari model tersebut, dibuatlah hipotesisnya sebagai berikut:

H1 : Fasilitas Individu secara positif berpengaruh terhadap kepuasan pelanggan

Faktor Individual digambarkan sebagai lapisan pertama ketika sebuah website social commerce digunakan oleh pelanggan. Faktor individual yang dimaksudkan adalah fitur personal yang disediakan oleh website. Huang dan Beyoucef mendeskripsikan fitur individu sebagai ketersediaan fasilitas untuk menempatkan profil pribadi, aktivitas pribadi individu yang dapat dibagikan kepada individu lain dan menarik interaksi sebagai ciri khas dari social commerce yaitu hubungan antar pelanggan. Social commerce yang menyediakan fasilitas individu yang sesuai, maka dapat memenuhi karakteristik sebuah social commerce. (Huang \& Beyoucef, 2013)

H2: Fasilitas Komunikasi secara positif berpengaruh terhadap kepuasan pelanggan

Fasilitas komunikasi merupakan lapisan kedua pada website social commerce. Komunikasi merupakan karakteristik social commerce yang mendukung interaksi pelanggan untuk bersosialisasi (Huang \& Beyoucef, 2013). Komunikasi menjadi aspek yang juga dapat mendukung pada kepercayaan pelanggan ketika melakukan pembelian melalui social commerce. Pelanggan dapat berbagi informasi dan konten kepada pelanggan lain dan mencapai suatu kesimpulan dan interaksi sosial. Kim dan Noh (2012) menginvestigasi faktor komunikasi terhadap peningkatan kepercayaan pelanggan online dalam berbelanja, dan memegang peranan yang cukup penting dalam menentukan kepercayaan online tersebut.

\section{H3: Kualitas Informasi secara positif} berpengaruh terhadap kepuasan pelanggan

Kualitas Informasi dapat menjadi faktor yang berpengaruh besar terhadap proses berbelanja online. Website berbelanja online seperti e-commerce sangat mengandalkan kualitas informasi tentang produk 
yang ditampilkan ke dalam website. Alsibly

menginvestigasi kualitas informasi sebagai salah satu faktor yang turut mempengaruhi kepuasan pelanggan social commerce dalam berbelanja online. Kim dan Noh (2012) juga menemukan bahwa kualitas informasi seperti keakuratan informasi mempengaruhi kepercayaan pelanggan dalam berbelanja.

\section{H4 : Kualitas Sistem secara positif berpengaruh terhadap kepuasan pelanggan.}

Kualitas Sistem merupakan aspek teknikal yang ditampilkan pada sebuah website. Huang dan Beyoucef (2013) mengidentifikasi kualitas sistem sebagai salah satu faktor yang mempengaruhi dalam website jual beli online. Sebelum berinteraksi dengan informasi didalam sebuah website, pengguna atau pelanggan harus dapat mengakses website tersebut terlebih dahulu, seperti kemampuan akses dan kegunaan sistem tersebut. (McKinney et al, 2002)

\section{METODE RISET}

Metode Penelitian yang digunakan pada penelitian ini adalah metode kuantitatif dengan pengumpulan data menggunakan kuisioner yang disebar melalui google docs kepada pengguna internet yang pernah melakukan pembelanjaan melalui facebook dan kaskus. Objek penelitian dipilih sebagai contoh dari website social commerce. Pengambilan sampel dilakukan secara simple random sampling. Kuisioner dibuat terdiri dari 3 bagian yaitu bagian untuk profil responden (data demografi), bagian untuk pengujian karakteristik web social commerce (empat variabel), dan bagian untuk menguji kepuasan, responden diminta untuk mengisi salah satu tipe social commerce yang paling sering dikunjungi dimana setiap pertanyaan pada kedua tipe adalah sama. Seluruh pertanyaan pada kuesioner kecuali pada bagian pertama menggunakan skala pengukuran ordinal yang diberi skala 1-4 dimana angka satu menunjukkan paling tidak puas dan skala 4 menunjukkan yang paling baik. Pengujian secara statistik dilakukan dengan bantuan software SPSS 22. 


\section{PEMBAHASAN}

Berikut akan dipaparkan pengolahan data dari hasil kuisioner yang telah dikembalikan responden kepada penulis. Dari kuesioner yang telah disebar melalui bantuan google docs, sebanyak 138 kuesioner yang terisi dengan baik. Kemudian, dilakukan seleksi terhadap kuisioner tersebut untuk mengambil data yang dapat diolah dan valid dapat digunakan untuk perhitungan yaitu sebanyak 94 sampel kuisioner dengan karakteristik responden pria sebanyak 54 orang dan responden wanita sebanyak 40 orang. Sebanyak 42 orang responden yang pernah melakukan pembelanjaan online di Kaskus.co.id dan sebanyak 52 orang responden memilih berbelanja melalui sosial media.

\section{Analisis Data}

Sebagai langkah pertama, penulis melakukan uji korelasi untuk menentukan apakah varibel yang diuji valid dan dapat digunakan, serta melakukan uji regresi untuk menentukan seberapa besar sebetulnya pengaruh antar variabel dalam penelitian ini. Tabel 1.1 sampai dengan Tabel 1.5 adalah hasil analisis yang telah dilakukan:

Tabel 1.1 Hasil Uji Korelasi Variabel Fasilitas Individu

Correlations

\begin{tabular}{|c|c|c|c|c|c|c|}
\hline & & Individual & Individual & Individual & Individual & Total_Individual \\
\hline \multirow[t]{3}{*}{ Individual } & Pearson Correlation & 1 & $.337 * *$ & $.260 * *$ & $.227 * *$ & $.643 * *$ \\
\hline & Sig. (2-tailed) & & .001 & .011 & .028 & .000 \\
\hline & $\mathrm{N}$ & 94 & 94 & 94 & 94 & 94 \\
\hline \multirow[t]{3}{*}{ Individual } & Pearson Correlation & $.337 * *$ & 1 & $.347 * *$ & $.188 * *$ & $.684 * *$ \\
\hline & Sig. (2-tailed) & .001 & & .001 & .069 & .000 \\
\hline & $\mathrm{N}$ & 94 & 94 & 94 & 94 & 94 \\
\hline \multirow[t]{3}{*}{ Individual } & Pearson Correlation & $.260 * *$ & $.347 * *$ & 1 & $.463 * *$ & $.689 * *$ \\
\hline & Sig. (2-tailed) & .011 & .001 & & .000 & .000 \\
\hline & $\mathrm{N}$ & 94 & 94 & 94 & 94 & 94 \\
\hline \multirow[t]{3}{*}{ Individual } & Pearson Correlation & $.227 *$ & .188 & $.463 * *$ & 1 & $.689 * *$ \\
\hline & Sig. (2-tailed) & .028 & .069 & .000 & & .000 \\
\hline & $\mathrm{N}$ & 94 & 94 & 94 & 94 & 94 \\
\hline \multirow[t]{3}{*}{ Total_Individual } & Pearson Correlation & $.643 * *$ & $.684 * *$ & $.748 * *$ & $.689 * *$ & 1 \\
\hline & Sig. (2-tailed) & .000 & .000 & .000 & .000 & \\
\hline & $\mathrm{N}$ & 94 & 94 & 94 & 94 & 94 \\
\hline
\end{tabular}

** Correlation significant at the 0.01 level (2-tailed)

* Correlation significant at the 0.05 level (2-tailed) 
Tabel 1.2 Hasil Uji Korelasi Variabel Fasilitas Komunikasi

Correlations

\begin{tabular}{|c|c|c|c|c|c|c|}
\hline & & Komunikasi & Komunikasi & Komunikasi & Komunikasi & Total_Komunikasi \\
\hline \multirow[t]{3}{*}{ Komunikasi } & Pearson Correlation & 1 & $.412 * *$ & $.330 * *$ & $.174 * *$ & $.669 * *$ \\
\hline & Sig. (2-tailed) & & .000 & .001 & .093 & .000 \\
\hline & $\mathrm{N}$ & 94 & 94 & 94 & 94 & 94 \\
\hline \multirow[t]{3}{*}{ Komunikasi } & Pearson Correlation & $.412 * *$ & 1 & $.323 * *$ & $.172 * *$ & $.706 * *$ \\
\hline & Sig. (2-tailed) & .000 & & .002 & .098 & .000 \\
\hline & $\mathrm{N}$ & 94 & 94 & 94 & 94 & 94 \\
\hline \multirow[t]{3}{*}{ Komunikasi } & Pearson Correlation & $.330 * *$ & $.323 * *$ & 1 & $.275 * *$ & $.726 * *$ \\
\hline & Sig. (2-tailed) & .001 & .002 & & .007 & .000 \\
\hline & $\mathrm{N}$ & 94 & 94 & 94 & 94 & 94 \\
\hline \multirow[t]{3}{*}{ Komunikasi } & Pearson Correlation & .174 & .172 & $.275 * *$ & 1 & $.595 * *$ \\
\hline & Sig. (2-tailed) & .093 & .098 & .007 & & .000 \\
\hline & $\mathrm{N}$ & 94 & 94 & 94 & 94 & 94 \\
\hline \multirow[t]{3}{*}{ Total_Komunikasi } & Pearson Correlation & $.669 * *$ & $.706 * *$ & $.726 * *$ & $.595 * *$ & 1 \\
\hline & Sig. (2-tailed) & .000 & .000 & .000 & .000 & \\
\hline & $\mathrm{N}$ & 94 & 94 & 94 & 94 & 94 \\
\hline
\end{tabular}

** Correlation significant at the 0.01 level (2-tailed)

Tabel 1.3 Hasil Uji Korelasi Variabel Kualitas Informasi

\section{Correlations}

\begin{tabular}{|c|c|c|c|c|c|c|}
\hline & & $\begin{array}{c}\text { Kualitas } \\
\text { Informasi }\end{array}$ & $\begin{array}{l}\text { Kualitas } \\
\text { Informasi }\end{array}$ & $\begin{array}{c}\text { Kualitas } \\
\text { Informasi }\end{array}$ & $\begin{array}{l}\text { Kualitas } \\
\text { Informasi }\end{array}$ & $\begin{array}{c}\text { Total_Kualitas } \\
\text { Informasi }\end{array}$ \\
\hline Kualitas & Pearson Correlation & 1 & $.462 * *$ & $.419 * *$ & $.396 * *$ & $.734 * *$ \\
\hline \multirow[t]{2}{*}{ Informasi } & Sig. (2-tailed) & & .000 & .000 & .000 & .000 \\
\hline & $\mathrm{N}$ & 94 & 94 & 94 & 94 & 94 \\
\hline Kualitas & Pearson Correlation & $.462 * *$ & 1 & $.433 * *$ & $.456 * *$ & $.780 * *$ \\
\hline \multirow[t]{2}{*}{ Informasi } & Sig. (2-tailed) & .000 & & .000 & .000 & .000 \\
\hline & $\mathrm{N}$ & 94 & 94 & 94 & 94 & 94 \\
\hline Kualitas & Pearson Correlation & $.419 * *$ & $.433 * *$ & 1 & $.567 * *$ & $.788 * *$ \\
\hline \multirow{2}{*}{ Informasi } & Sig. (2-tailed) & .000 & .000 & & .000 & .000 \\
\hline & $\mathrm{N}$ & 94 & 94 & 94 & 94 & 94 \\
\hline Kualitas & Pearson Correlation & $.396^{* *}$ & $.456 * *$ & $.567 * *$ & 1 & $.773 * *$ \\
\hline \multirow{2}{*}{ Informasi } & Sig. (2-tailed) & .000 & .000 & .000 & & .000 \\
\hline & $\mathrm{N}$ & 94 & 94 & 94 & 94 & 94 \\
\hline Total_Kualitas & Pearson Correlation & $.734 * *$ & $.780 * *$ & $.788 * *$ & $.773 * *$ & 1 \\
\hline \multirow[t]{2}{*}{ Informasi } & Sig. (2-tailed) & .000 & .000 & .000 & .000 & \\
\hline & $\mathrm{N}$ & 94 & 94 & 94 & 94 & 94 \\
\hline
\end{tabular}

** Correlation significant at the 0.01 level (2-tailed) 
Tabel 1.4 Hasil Uji Korelasi Variabel Kualitas Sistem

Correlations

\begin{tabular}{|c|c|c|c|c|c|c|}
\hline & & $\begin{array}{l}\text { Kualitas } \\
\text { Sistem } \\
\end{array}$ & $\begin{array}{l}\text { Kualitas } \\
\text { Sistem } \\
\end{array}$ & $\begin{array}{l}\text { Kualitas } \\
\text { Sistem }\end{array}$ & $\begin{array}{l}\text { Kualitas } \\
\text { Sistem }\end{array}$ & $\begin{array}{c}\text { Total_Kualitas } \\
\text { Sistem }\end{array}$ \\
\hline \multirow[t]{3}{*}{ Kualitas Sistem } & Pearson Correlation & 1 & $.481 * *$ & $.441 * *$ & $.486 * *$ & $.784 * *$ \\
\hline & Sig. (2-tailed) & & .000 & .000 & .000 & .000 \\
\hline & $\mathrm{N}$ & 94 & 94 & 94 & 94 & 94 \\
\hline \multirow[t]{3}{*}{ Kualitas Sistem } & Pearson Correlation & $.481 * *$ & 1 & $.358 * *$ & $.359 * *$ & $.707 * *$ \\
\hline & Sig. (2-tailed) & .000 & & .000 & .000 & .000 \\
\hline & $\mathrm{N}$ & 94 & 94 & 94 & 94 & 94 \\
\hline \multirow[t]{3}{*}{ Kualitas Sistem } & Pearson Correlation & $.441 * *$ & $.358 * *$ & 1 & $.637 * *$ & $.798 * *$ \\
\hline & Sig. (2-tailed) & .000 & .000 & & .000 & .000 \\
\hline & $\mathrm{N}$ & 94 & 94 & 94 & 94 & 94 \\
\hline \multirow[t]{3}{*}{ Kualitas Sistem } & Pearson Correlation & $.486 * *$ & $.359 * *$ & $.637 * *$ & 1 & $.797 * *$ \\
\hline & Sig. (2-tailed) & .000 & .000 & .000 & & .000 \\
\hline & $\mathrm{N}$ & 94 & 94 & 94 & 94 & 94 \\
\hline Total_Kualitas & Pearson Correlation & $.784 * *$ & $.707 * *$ & $.798 * *$ & $.797 * *$ & 1 \\
\hline \multirow[t]{2}{*}{ Sistem } & Sig. (2-tailed) & .000 & .000 & .000 & .000 & \\
\hline & $\mathrm{N}$ & 94 & 94 & 94 & 94 & 94 \\
\hline
\end{tabular}

** Correlation significant at the 0.01 level (2-tailed)

Tabel 1.5 Hasil Uji Korelasi Variabel Kepuasan Pelanggan

\section{Correlations}

\begin{tabular}{llrrrrr}
\hline & & $\begin{array}{c}\text { Kepuasan } \\
\text { Pelanggan }\end{array}$ & $\begin{array}{c}\text { Kepuasan } \\
\text { Pelanggan }\end{array}$ & $\begin{array}{c}\text { Kepuasan } \\
\text { Pelanggan }\end{array}$ & $\begin{array}{c}\text { Kepuasan } \\
\text { Pelanggan }\end{array}$ & $\begin{array}{c}\text { Total_Kepuasan } \\
\text { Pelanggan }\end{array}$ \\
\hline Kepuasan & Pearson Correlation & 1 & $.445^{* *}$ & $.356^{* *}$ & $.313^{* *}$ & $.716^{* *}$ \\
Pelanggan & Sig. (2-tailed) & & .000 & .000 & .002 & .000 \\
& $\mathrm{~N}$ & 94 & 94 & 94 & 94 & 94 \\
\hline Kepuasan & Pearson Correlation & $.445^{* *}$ & 1 & $.316^{* *}$ & $.328^{* *}$ & $.714^{* *}$ \\
Pelanggan & Sig. (2-tailed) & .000 & & .002 & .001 & .000 \\
& $\mathrm{~N}$ & 94 & 94 & 94 & 94 & 94 \\
\hline Kepuasan & Pearson Correlation & $.356^{* *}$ & $.316^{* *}$ & 1 & $.592^{* *}$ & $.767^{* *}$ \\
Pelanggan & Sig. (2-tailed) & .000 & .002 & & .000 & .000 \\
& $\mathrm{~N}$ & 94 & 94 & 94 & 94 & 94 \\
\hline Kepuasan & Pearson Correlation & $.313^{* *}$ & $.328^{* *}$ & $.592^{* *}$ & 1 & $.753^{* *}$ \\
Pelanggan & Sig. (2-tailed) & .002 & .001 & .000 & .000 \\
& $\mathrm{~N}$ & 94 & 94 & 94 & 94 & 94 \\
\hline Total_Kepuasan & Pearson Correlation & $.716^{* *}$ & $.714^{* *}$ & $.767^{* *}$ & $.753^{* *}$ & .000 \\
Pelanggan & Sig. (2-tailed) & .000 & .000 & .000 & .000 & 1 \\
& $\mathrm{~N}$ & 94 & 94 & 94 & 94 & 94 \\
\hline
\end{tabular}

** Correlation significant at the 0.01 level (2-tailed)

Pada tabel 1.1, tabel 1.2, tabel 1.3, tabe1.4, dan tabel 1.5 dapat ditafsirkan hasilnya variabel yang diteliti, seluruhnya valid karena memiliki nilai uji diatas r-tabel yaitu 0,202 sehingga menunjukkan semua pertanyaan yang diajukan mampu mewakili variabel yang diujikan serta secara sah bisa digunakan dalam penelitian ini dan memiliki pengaruh untuk diuji dalam penelitian ini. 
Tabel 1.6 Model Summary

Model Summary

\begin{tabular}{|c|c|c|c|c|}
\hline Model & $\mathrm{R}$ & R Square & $\begin{array}{c}\text { Adjusted R } \\
\text { Square }\end{array}$ & $\begin{array}{l}\text { Std. Error of } \\
\text { the Estimate }\end{array}$ \\
\hline 1 & $.750^{\mathrm{a}}$ & .563 & .543 & .30645 \\
\hline
\end{tabular}

Pada tabel 1.6, terlihat bahwa nilai $r$ sebesar 0,750 yang menyatakan bahwa variabel yang diujikan yaitu variabel fasilitas individu, fasilitas komunikasi, kualitas informasi dan kualitas sistem memiliki pengaruh sebesar $75 \%$ terhadap kepuasan pelanggan. Sedangkan nilai adjusted $\mathrm{R}$ square menjelaskan bahwa variasi variabel dependent (Y), dengan angka adjusted $R$ square sebesar 0.563 menunjukkan bahwa variabel-variabel yang sudah diujikan memberikan pengaruh sebesar $56.3 \%$ sedangkan sisanya yaitu $53.1 \%$ dapat dijelaskan oleh faktor-faktor lain yang tidak dijelaskan pada penelitian ini.

Tabel 1.7 Hasil Uji Regresi Linier Berganda

Coefficients ${ }^{a}$

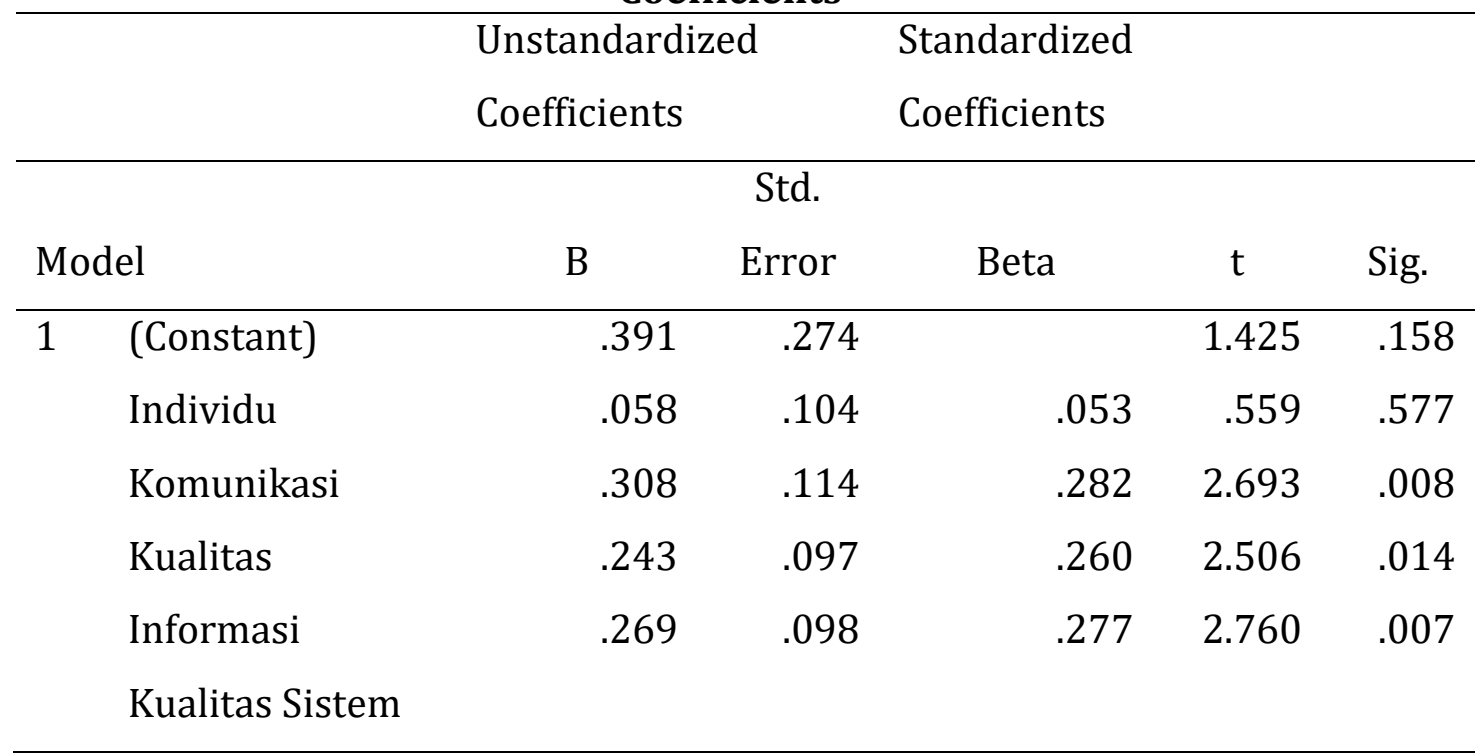

a. Dependent Variable: Kepuasan 
H1: Fasilitas Individu secara positif berpengaruh terhadap kepuasan pelanggan

Hasil uji dari hipotesis 1 diketahui bahwa tabel coefficients bahwa tingkat signifikansi $p$ value dari variabel individual berada pada nilai 0,577 yang berarti signifikansi $p$ value $>0,05$ sehingga hipotesis $\mathrm{H} 1$ tidak dapat diterima atau tidak signifikan, dimana penelitian ini tidak sesuai dengan penelitian sebelumnya yang dilakukan oleh Huang dan Beyoucef (2013) yang menyatakan faktor individu adalah karakteristik yang harus dimiliki oleh social commerce untuk menarik pelanggan. Namun hasil penelitian ini juga bisa dikatakan menunjukan pola dari masyarakat Indonesia yang lebih cenderung tidak selalu memanfaatkan fasilitas individu. Dari hasil pengamatan dan wawancara dengan responden, menunjukan bahwa responden cenderung memilih untuk bisa berbelanja tanpa harus menggunakan fasilitas individu seperti melakukan login, update profile dan semua yang berhubungan dengan eksistensi diri dari calon penjual, sehingga dalam penelitian ini maka fasilitas individu tidak menjadi variabel yang terlalu berpengaruh terhadap kepuasan pelanggan.

\section{H2: Fasilitas Komunikasi secara positif berpengaruh terhadap} kepuasan pelanggan

Hasil uji dari hipotesis 2 diketahui bahwa fasilitas komunikasi diketahui secara signifikan memberikan pengaruh karena nilai ujinya memiliki nilai 0,008 yang berarti signifikansi $p$ value $<0,05$ sehingga hipotesis $\mathrm{H} 2$ dapat diterima atau signifikan. Penelitian ini sesuai dengan penelitian yang sudah dilakukan oleh Huang dan Beyoucef (2013) dimana dengan tersedianya fasilitas komunikasi memungkinkan setiap user untuk mendapatkan informasi yang tepat terkait dengan produk atau jasa yang ditawarkan oleh penjual. Selain itu memungkinkan juga dengan adanya fasilitas komunikasi sehingga terciptanya komunikasi yang baik antara penjual, calon pembeli. Hasil uji juga significant terhadap penelitian oleh Kim dan Noh (2012) yang menyatakan faktor fasilitas komunikasi ikut mempengaruhi kepercayaan konsumen.

H3: Kualitas Informasi secara positif berpengaruh terhadap kepuasan pelanggan

Hasil uji dari hipotesis 3 diketahui 
bahwa fasilitas komunikasi diketahui secara signifikan memberikan pengaruh karena nilai ujinya memiliki nilai 0,014 yang berarti signifikansi $p$ value $<0,05$ sehingga hipotesis H3 dapat diterima atau signifikan. Penelitian ini sudah sesuai dengan penelitian yang sudah dilakukan oleh Huang dan Beyoucef (2013) karena semakin terupdatenya kualitas informasi maka akan semakin memberikan kepuasan pelanggan dalam melakukan transaksi di social commerce. Hasil uji juga sesuai dengan penelitian Alsibly (2014) yang menginvestigasi kualitas informasi sebagai salah satu faktor yang berpengaruh pada kepuasan pelanggan yang berbelanja melalui social commerce.

H4 : Kualitas Sistem secara positif berpengaruh terhadap kepuasan pelanggan

Hasil uji dari hipotesis 4 diketahui bahwa fasilitas komunikasi diketahui secara signifikan memberikan pengaruh karena nilai ujinya memiliki nilai 0,007 yang berarti signifikansi $p$ value $<0,05$ sehingga hipotesis $\mathrm{H} 4$ dapat diterima atau signifikan. Penelitian ini sudah sesuai dengan penelitian yang sudah dilakukan oleh Alsibly (2014) dimana semakin baik sistem yang dirancang akan semakin memudahkan transaksi dilakukan (user friendly) selain daripada itu kualitas sistem yang baik akan mampu membuat pelanggan untuk kembali untuk melakukan transaksi ataupun hanya untuk melihat-lihat (Koufaris, 2002).

\section{KESIMPULAN DAN IMPLIKASI}

Tujuan dari penelitian ini adalah untuk menguji apakah benar beberapa karakteristik social commerce ikut mempengaruhi kepuasan pelanggan dalam berbelanja. Berdasarkan hasil analisis data yang telah dilakukan, dapat diambil kesimpulan bahwa faktor-faktor yang mendukung kepuasan pengguna dalam berbelanja melalui website social commerce adalah fasilitas komunikasi, kualitas informasi, dan kualitas sistem yang merupakan karakteristik dari social commerce. Faktor individual ternyata tidak berpengaruh secara significant dalam menentukan kepuasan pelanggan dalam berbelanja. Meskipun faktor-faktor ini mengambil tempat sebesar $56.3 \%$ dari faktor-faktor lain yang tidak diuji pada penelitian ini, 
Journal of Management Vol.13, No.1, January 2016: 122-139 and Business Review

namun cukup memberikan dampak

bahwa ketika membangun website

social commerce, faktor-faktor ini

perlu dipertimbangkan yaitu

menyediakan informasi yang akurat, fasilitas berbagi informasi yang sesuai dan mudah digunakan, serta kualitas sistem website yang mudah diakses dan user friendly.

Lebih jauh untuk penyempurnaan dari penelitian ini, dapat ditambahkan faktor lain yang turut diuji untuk membuktikan bahwa social commerce memang benar mempengaruji pelanggan dalam berbelanja sehingga rekomendasi yang didapatkan menjadi lebih banyak. 
Karakteristik Desain ... (Cadelina C., Ratna S., dan Riswan E.)

\section{DAFTAR PUSTAKA}

Alshibly, H. H. (2014). A Free Simulation Experiment to Examine the Effect of Social commerce Website Quality and Customer Pyschological Empowerment on Customers' Satisfaction. Journal of Business Studies Quarterly, 21-40.

Anderson, R. E \& Srinivasan,, S. S (2003). E-Satisfaction and E-Loyalty: A Contingency Framework. Psychology \& Marketing, Vol. 20 No. 2, pp. 123138

Bansal, G., \& Chen, L. (2011). If They Trust our e-commerce site, will they trust our social commerce too? Differentiating the trust in e-commerce an scommerce: The Moderating role of privacy and security concerns. MWAIS 2011 Proceedings.

Cheung, C.M.K., Lee, M.K.O. (2005). Research Framework for Consumer Satisfaction with Internet Shopping. Sprouts: Working Papers on Information Systems, 5 (26).

Constantinides, E., Romero, L.R., and Boria, M.A.G. (2008). Social Media : A New Frontier for Retailers?.European Retail Research, Vol. 22.

Eid, M. I. (2011). Determinants of E-Commerce Customer Satisfaction, Trust, and Loyalty in Saudi Arabia. Journal of Electronic Commerce Research, 78-93.

Huang, Z., \& Benyoucef, M. (2013). From e-commerce to social commerce: A close Look at Design Features. Electronic Commerce Research and Application 12 , 246-259.

Jung, L. S. (2014). A Study of Affecting the Purchasing Intention of Social Commerce. International Journal of Software Engineering and Its Application.

Kim, S., \& Noh, M. J. (2012). Determinants Influencing Consumers' Trust and Trust Performance of Social commerce and Moderating Effect of Experience. Science Alert

Koufaris, Marious. (2002). Applying the Technology Acceptance Model and Flow Theory to Online Consumer Behaviour. Information System Research. 205-224

Luo, J., Ba, S., \& Zhang, H. (2012). The Effectiveness of Online Shopping Characteristics and Well Designed Websites on Satisfaction. MIS Quartely, A1-A9.

McKinney, V., Yoon, K., and Zahedi, F.M (2002). The Measurement of WebCustomer Satisfaction: An Expectation and Disconfirmation Approach. Information System Research, Vol. 13 (3), pp. 296-315

Pangerapan, S. A. (2015, Maret Senin). Retrieved Juli Jumat, 2015, from Asosiasi Penyelenggara Jasa Internet Indonesia: apjii.or.id

Saundage, D., \& Lee, C. Y. (2011). Social commerce Activities - a Taxonomy. 22nd Australasian Conference on Information System. Sydney.

Tabaei, Z., Fathian, M., \& Gholamian, M. R. (2011). Effective Factors on Electronic Customer Satisfaction. International Conference on Information and Financial Engineering, 579-582. 
Journal of Management Vol.13, No.1, January 2016: 122-139 and Business Review

Zhang, P. \& Dran, G. V. (2001). User Expectation and Rangkings of Quality Factors in Different Website Domains. International Journal of Electronic Commerce, Vol. 6, No. 2, pp. 9-33

Zhou, L., Zhang, P., \& Zimmwemann, H. D. (2013). Social commerce Research: an Integrated View. Electronic Commerce Research and Application 